\title{
Genotype Distribution of Hepatitis C Virus in Hatay Province of Turkey
}

\author{
Hatay Ilinde Hepatit C Virüs Genotip Dağılımı, Türkiye
}

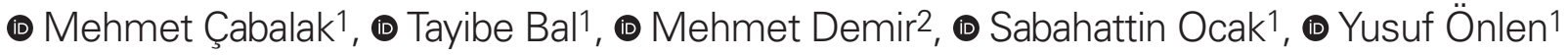 \\ ${ }^{1}$ Hatay Mustafa Kemal University Faculty of Medicine, Department of Infectious Disease and Clinical Microbiology, Hatay, Turkey \\ 2 Hatay Mustafa Kemal University Faculty of Medicine, Department of Gastroenterology, Hatay, Turkey
}

\begin{abstract}
Objectives: The treatment duration and response of chronic hepatitis $\mathrm{C}(\mathrm{CHC})$ are closely related to the genotypes of hepatitis $\mathrm{C}$ virus $(\mathrm{HCV})$. This study aimed to determine the genotype distributions among $\mathrm{CHC}$ patients in the Hatay province of Turkey. Materials and Methods: In this study, demographic data of 589 patients who received a therapy for $\mathrm{CHC}$ at the infectious diseases and gastroenterology clinics between June 2016 and May 2019 were retrieved from the hospital information system and medical charts of the patients and were retrospectively reviewed.

Results: The most common HCV genotype in our study was genotype $1 \mathrm{~b}(66.9 \%)$, followed by genotype $2(10.5 \%)$, genotype 1a $(7.3 \%)$, genotype $4(7.1 \%)$, genotype $3(7 \%)$, and mixed genotype $(1.2 \%)$. Six of the mixed genotypes were identified as $1 b+4$, while one was $1 a+3$. There was a statistically significant difference between females and males with regards to the HCV genotypes $(p<0.001)$. Patients with genotype $1 b$ tended to be older, while patients with genotypes 3 and 4 tended to be younger.

Conclusion: Genotype $1 \mathrm{~b}$ is the most common HCV genotype in Hatay province, and it is followed by genotypes 2, 1a, 4 and 3. Compared to the studies conducted in previous years in Turkey, our study identified a lower rate for genotype $1 \mathrm{~b}$, along with an increase in the distribution rates of the other genotypes. Monitoring the changes in HCV genotype distribution is of vital importance to develop effective strategies in the treatment of HCV.

Keywords: Hepatitis C virus, genotype, Hatay
\end{abstract}

\section{$\ddot{O Z Z}$}

Amaç: Kronik Hepatit $\mathrm{C}(\mathrm{KHC})$ enfeksiyonunun tedavi süresi ve tedaviye verilen yanıt hepatit $\mathrm{C}$ virüs $(\mathrm{HCV})$ genotipleri ile yakından ilişkilidir. Coğrafi bölgelere göre HCV genotiplerinin dağılımında farklııklar vardır. Bu çalışmada Hatay ilindeki KHC hastalarında genotip dağııımlarının belirlenmesi amaçlanmıştır.

Gereç ve Yöntemler: Çalışmada KHC nedeni ile Haziran 2016-Mayıs 2019 tarihleri arasında enfeksiyon hastalıkları ve gastroenteroloji klinikleri tarafından tedavi başlanan 589 hastanın demografik verileri, hastane elektronik bilgi sistemi ve hasta dosyalarından retrospektif olarak incelendi.

Bulgular: HCV-RNA pozitif 589 hastada HCV genotiplerinin yüzdesi genotip 1b: \%66,9, genotip 1a: \%7,3, genotip 2: \%10,5, genotip 3: $41 \% 7$, genotip 4: \%7,1 ve mix genotip: \% 1,2 olarak tespit edildi. Mix genotiplerin 6 tanesi $1 \mathrm{~b}+4$, bir tanesi $1 \mathrm{a}+3$ olarak belirlenmiștir. Kadın ve erkek cinsleri arasında HCV genotipleri arasında istatistiksel olarak anlamlı farklılık görüldü $(p<0,001)$. Genotip 1b hastaları daha ileri yaşlarda, genotip 3 ve genotip 4 hastalarının daha genç yaşlarda olduğu tespit edildi.

Sonuç: Hatay'da HCV genotip $1 \mathrm{~b}$ en yaygın genotiptir ve bunu genotip 2, 1a, 4 ve 3 izlemektedir. Bizim çalışmamızda ülkemizdeki önceki yıllarda yapılan çalışmalara göre genotip $1 b$ daha düşük tespit edilmiştir ve diğer genotiplerin dağlımında artış olduğu saptanmıştır. HCV genotip dağlımındaki değişikliklerin izlenmesi HCV'nin tedavisinde etkili stratejilerin geliștirilmesinde hayati öneme sahiptir. Anahtar Kelimeler: Hepatit C virüs, Genotip, Hatay

Çabalak M, Bal T, Demir M, Ocak S, Önlen Y. Genotype Distribution of Hepatitis C Virus in Hatay Province of Turkey. Viral Hepat J. 2020;26:56-60. 


\section{Introduction}

Hepatitis C virus ( $\mathrm{HCV}$ ) causes both acute and chronic liver disease. It is estimated that there are 71 million people around the world that are infected with HCV. The disease becomes chronic and leads to the development of cirrhosis and liver cancer in a significant portion of patients. Approximately 399,000 people die every year due to hepatitis C-related cirrhosis and hepatocellular cancer (1).

Genome sequencing studies have identified seven genotypes and 67 subtypes of HCV (2). Methods used to identify the genotypes of HCV include DNA sequence analysis, type-specific polymerase chain reaction (PCR), PCR-restriction fragment length polymorphism (RFLP), and the line probe assay, which is a commercial kit (3).

The distribution of HCV genotypes varies according to geographic regions. Genotypes 1 and 2 are the most common genotypes in the United States and Japan (4). Genotype 3 is the most common in Southeast Asia; genotype 4 is the most common in the Middle East, Egypt and Central Africa; genotype 5 is the most common in South Africa; and genotype 6 is the most common in Asia (5). Genotype 7 is found in Congo, Africa, while genotype $1 \mathrm{~b}$ is reported to be the most common in Mediterranean countries (6). Studies in Turkey have shown that, similarly to the general distribution of genotypes worldwide, HCV genotype 1 is the most common genotype in the country $(7,8)$.

Although pangenotypic therapies have been developed, the knowledge of the HCV genotype maintains its significance among the factors affecting the selection of the treatment regimen, the duration of treatment and the treatment success (9). This study aimed to determine the genotype distributions among patients with chronic HCV in the Hatay province of Turkey that is important in predicting the response to therapy.

\section{Materials and Methods}

This retrospective cross-sectional study retrospectively reviewed the data for 589 patients who were started on a therapy for chronic HCV between June 2016 and May 2019 by the Hatay Mustafa Kemal University Faculty of Medicine Healthcare Application Hospital, Clinic of Infections Diseases and Gastroenterology. The demographic data of the patients were retrieved from the hospital's electronic information system and the patients' files. Patients under the age of 18, patients with a co-infection with HBV or Human Immunodeficiency Virus, and foreign nationals were not included in the study.

For viral load determination, HCV-RNA levels were studied using real-time PCR method (COBAS AmpliPrep/COBAS Tagman, Roche Diagnostics, Germany), while the HCV genotypes were studied using the Real Time HCV Genotype II system (Anatolia geheworks, Turkey).

The study was performed with the approval of the Hatay Mustafa Kemal University Faculty of Medicine Ethics Committee (approval number: 09, date: 27.06.2019). Due to the retrospective design of the study informed consent was not obtained.

\section{Statistical Analysis}

Statistical analyses were performed using the SPSS software version 21 . The variables were investigated using histograms and
Shapiro-Wilk test to determine whether or not they are normally distributed. The Mann-Whitney $U$ test was used to compare the non-parametric variables. The chi-square test or Fisher's exact test, where appropriate, was used for categorical variables. A p-value of 0.05 or lower was considered to show a statistically significant result.

\section{Results}

The 589 patients who met the study inclusion criteria consisted of $286(48.6 \%)$ males and $303(51.4 \%)$ females with a median age of 64 years [interquartile range (IQR): $52-72$ years]. The most common HCV genotype in our study was genotype 1b $(66.9 \%$; $n=399)$, which was followed by genotype 2 (10.5\%; $n=62)$, genotype 1a (7.3\%; $n=43)$, genotype $4(7.1 \% ; n=42)$ and genotype $3(7 \% ; n=41)$ (Figure 1). Six of the mixed genotypes were identified as $1 \mathrm{~b}+4$, while one was identified as $1 a+3$. Genotypes 5 and 6 were not identified in our study.

A statistically significant difference was observed between female and male patients in terms of HCV genotype distribution $(p<0.001)$. Patients with genotype $1 \mathrm{~b}$ were predominantly female, with a rate of $58.4 \%$, while cases infected with genotypes 2, 3 and 4 were predominantly male $(59.7 \%, 90 \%$ and $88 \%$, respectively).

The median age was 67 among cases with genotype $1 \mathrm{~b}$ (IQR: 59-74), 60.5 among cases with genotype 2 (IQR: 34.2-75), 28 among cases with genotype 3 (IQR: 23-33), 34 among cases with genotype 4 (IOR: 30-45.5), 62 among cases with genotype 1a (IQR: 50-70), and 68 among cases with mixed genotype (IQR: 33-71). The mean age of patients infected with genotype 1 was higher than the mean age of the patients infected with other genotypes, and this difference was found to be statistically significant $(p<0.001)$. Patients with genotype 3 and genotype 4 were younger $(p<0.001)$ (Figure 2$)$.

\section{Discussion}

The distribution of HCV genotypes varies considerably around the world. The most commonly observed genotype among adult patients with HCV worldwide is genotype 1 with a rate of $49 \%$, and it is followed by genotype 3 (17.9\%), genotype 4 (16.8\%),

HCV Genotype distribution paterns of 589 patients

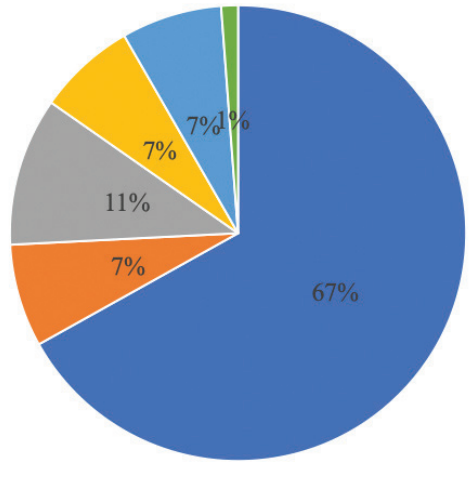

-GT $1 \mathrm{~b}=\mathrm{GT} 1 \mathrm{a}=\mathrm{GT} 2=\mathrm{GT} 3 \quad=\mathrm{GT} 4=\operatorname{Mixed} \mathrm{GT}$

Figure 1. Distribution patterns of HCV genotypes

HCV: Hepatitis C virus, GT: Genotype 
genotype $2(11 \%)$, genotype $5(2 \%)$ and genotype $6(1.4 \%)$ in descending order (10).

Studies conducted in Turkey on the distribution of $\mathrm{HCV}$ genotypes have found that genotype 1 is responsible for approximately $90 \%$ of $\mathrm{HCV}$ infections, with the majority being genotype $1 \mathrm{~b}$. Other genotypes are observed less frequently. The present study identified genotype 1 as the most frequent genotype, which is similar to the situation in Turkey and in the world. The most frequently observed HCV genotype in our study was determined as genotype $1 \mathrm{~b}(66.9 \%)$ Table 1.

In parallel with the data for Turkey, our study found high frequency rate for genotype $1 \mathrm{~b}$ (66.9\%). However, unlike other

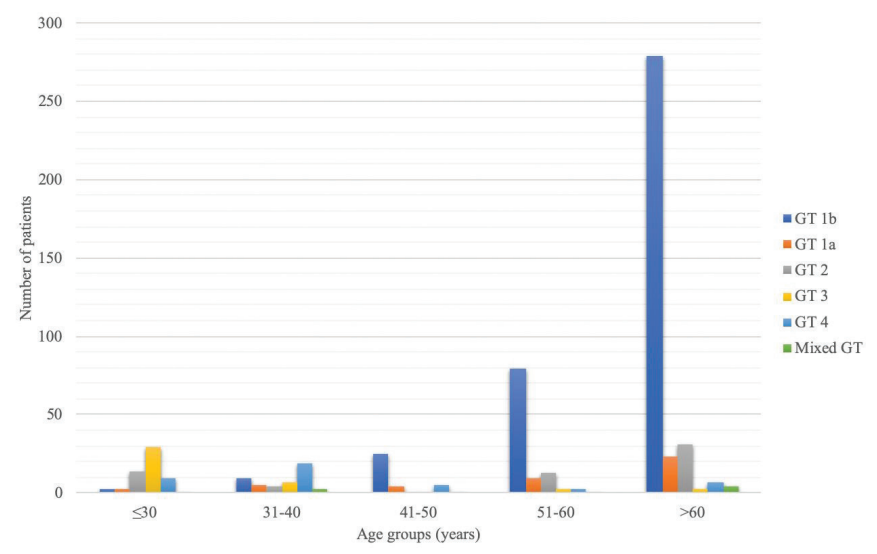

Figure 2. The genotype distribution according to age groups GT: Genotype studies, our study determined that the distribution of genotype $1 \mathrm{~b}$ has relatively decreased, while the distribution of other genotypes has increased. Our study also includes the highest number of patients from a single centre.

The studies of Oztürk et al. (18) in Adana and Antakya, Borcak et al. (25) in Nevşehir and Akgün et al. (27) in Adıyaman found the distribution of genotype 2 to be higher than those reported in previously conducted studies in Turkey. The researchers attributed this to the increase in the use of intravenous drugs and the geographic location of these provinces. While we also identified an increase in the distribution of genotype 2 in our study, we did not associate this with the use of intravenous drugs.

A look at certain studies that have been published in Turkey in recent years shows that there is an increase in the frequency of genotype $3(7,15,18,19,24,26)$. In a study performed by Sağlik et al. (24) in Antalya, the prevalence of genotype 3 was reported to be $11.1 \%$, and $40 \%$ of these cases were foreign nationals. The researchers attributed the change in genotype distribution of $\mathrm{HCV}$ to the fact that Antalya is one of the most visited cities in the world and it has a high rate of immigration. In a study performed by Kirisci et al. (19) in Kahramanmaraş, the prevalence of genotype 3 was reported to be $40 \%$, which is above the average values for Turkey. However, this observation may also be explained by the fact that the said study included a relatively small number of patients. Our study did not include foreign nationals, and $63.4 \%$ of patients with genotype 3 consisted of patients who used intravenous substances. This finding may also account for the fact that genotype 3 patients were generally younger.

Table 1. Distribution of hepatitis $C$ virus genotypes observed in studies from different provinces or regions of Turkey

\begin{tabular}{|c|c|c|c|c|c|c|c|c|c|}
\hline \multirow[t]{2}{*}{ Study group } & \multirow{2}{*}{$\begin{array}{l}\text { Number of } \\
\text { patients }\end{array}$} & \multirow[t]{2}{*}{ Year } & \multicolumn{6}{|c|}{ Genotypes } & \multirow[t]{2}{*}{ Provinces/Regions } \\
\hline & & & 1a & $1 \mathrm{~b}$ & 1 & 2 & 3 & 4 & \\
\hline Ozacar et al. (11) & 170 & 2001 & 10 & 81.2 & - & 2.4 & 0.6 & 1.2 & İzmir \\
\hline Altuglu et al. (13) & 345 & 2008 & 9.9 & 87.2 & - & 0.9 & 1.4 & 0.6 & İmir \\
\hline Celik et al. (14) & 178 & 2010 & 8.9 & 88.2 & - & 1.1 & 1.6 & - & Sivas \\
\hline Kayman et al. (17) & 375 & 2012 & 2.4 & 57.6 & 2.4 & 3.2 & 1.1 & 32 & Kayseri \\
\hline Oztürk et al. (18) & 639 & 2013 & 1.9 & 71.2 & - & 11.9 & 13.3 & 1.7 & Adana and Antakya \\
\hline Kirisci et al. (19) & 100 & 2013 & - & - & 60 & - & 40 & - & Kahramanmaraş \\
\hline Altuğlu et al. (20) & 535 & 2013 & 12.9 & 80.4 & 0 & 1.5 & 3.7 & 1.5 & İzmir \\
\hline Sağlik et al. (24) & 422 & 2014 & 14.7 & 63.3 & 5.4 & 3.5 & 11.1 & 1.6 & Antalya \\
\hline Borcak et al. (25) & 170 & 2014 & - & 37 & 45.1 & 14.5 & 1.2 & 0.6 & Nevsehir \\
\hline Zeytinli et al. (7) & 554 & 2017 & 23.1 & 56.5 & - & - & 17.3 & - & İstanbul \\
\hline Özer Balin et al. (26) & 71 & 2017 & - & - & $87.3 \%$ & 2.8 & 9.9 & - & Elazığ \\
\hline Akgün et al. (27) & 71 & 2018 & 8.4 & 71.8 & 4.2 & 11.27 & 4.2 & - & Adıyaman \\
\hline Karabulut et al. (8) & 412 & 2018 & 38.8 & 37.4 & 6.3 & 4.6 & 10.7 & 2.2 & İstanbul \\
\hline Our study & 589 & 2019 & 7,3 & 66.9 & - & 10.5 & 7 & 7.1 & Hatay \\
\hline
\end{tabular}


Our study identified an increase in the distribution of genotype 4. Gökahmetoğlu et al. (16) and Kayman et al. (17) previously determined that the prevalence of HCV genotype 4 is higher in Kayseri compared to its prevalence in the rest of the country, but the researchers did not discuss possible reasons for this finding. While the rate of genotype 4 in our study was lower compared to that in Kayseri, it was still higher compared to the rates reported in other centres across Turkey. The authors believe that the findings on genotype distribution can be explained by geographic location.

Genotypes 5 and 6 were not detected in our study. In the studies by Tezcan et al. (21) and Çizmeci (28) in Turkey, only one person was found to have genotype 6 .

A study carried out in Spain with 48,595 chronic HCV patients determined that genotypes 3 and genotype 4 patients are more common among men, while genotypes 1 and 2 patients are more common among women (29). Studies conducted in Western Europe, Russia and Israel have found similar results (30). In their study conducted in the Kahramanmaraş province of Turkey, Zeytinli et al. (7) observed no gender-related difference in genotype distribution, while in their study performed in Istanbul, Karabulut et al. (8) observed both age- and gender-related differences in genotype distribution, determining that genotypes 1 and 2 are more common among women, while genotype 3 and 4 are more common among men. In addition, they also observed genotype 1 being more frequent among elderly patients, and genotype 3 being more frequent among younger patients. In their study performed in Antalya, Sağlık et al. (24) observed that patients infected with genotype 1 are generally older than patients infected with the other genotypes; however, they identified no significant difference in terms of gender-related distribution among the patients infected with different genotypes. In our study, a significant difference was identified with regards to gender distribution between the patients infected with different genotypes, with genotypes 2, 3 and 4 being observed more commonly among males. It was found that genotype $1 \mathrm{~b}$ is common among the elderly, and that most of the infected patients are women (Figure 3).

\section{Study Limitations}

The most important limitation of our study was the fact that all data were obtained from patients with $\mathrm{CHC}$ who directly presented to our hospital to receive effective antiviral therapy. Since our study did not include patients with unknown hepatitis $\mathrm{C}$ status and those

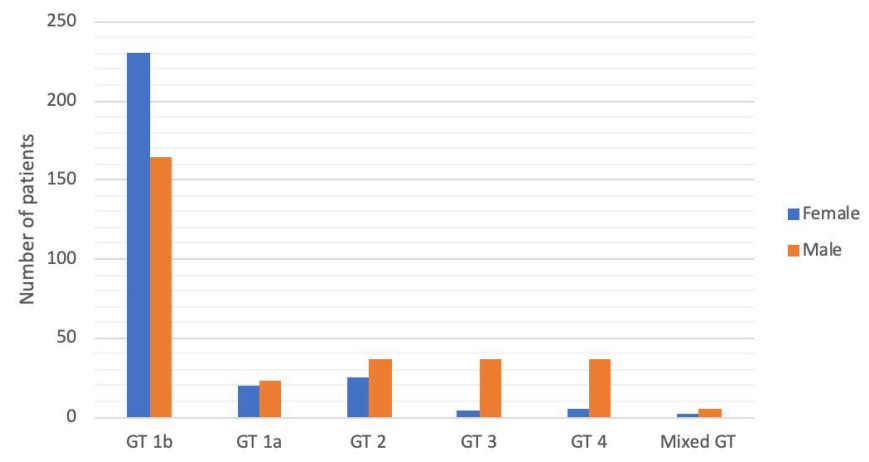

Figure 3. The genotype distribution according to gender GT: Genotype who do not seek therapy, care should be taken while interpreting the results of the present study.

\section{Conclusion}

In our study, the most common HCV genotype in Hatay province was genotype $1 \mathrm{~b}$, which was followed by genotypes 2 , $1 \mathrm{a}, 4$ and 3 in terms of frequency. Compared to studies in Turkey that have been performed in previous years, we identified a lower frequency rate for genotype $1 \mathrm{~b}$, along with an increase in the distribution of the other genotypes. Monitoring the changes in the distribution of HCV genotype continues to be important for the selection of effective HCV therapies and for predicting treatment response. It is observed that there are regional differences in the genotype distribution in Turkey, which is why we believe it is important for each region to know its own epidemiological data.

\section{Ethics}

Ethics committee approval: The study was performed with the approval of the Hatay Mustafa Kemal University Faculty of Medicine Ethics Committee (approval number: 09, date: 27.06.2019).

Informed Consent: Due to the retrospective design of the study informed consent was not obtained.

Peer-review: Externally peer-reviewed.

\section{Authorship Contributions}

Surgical and Medical Practices: M.Ç., T.B., M.D., S.O., Y.Ö., Concept: M.Ç., T.B., Design: M.Ç., T.B., Data Collection or Processing: M.Ç., T.B., Analysis or Interpretation: M.Ç., T.B., M.D., S.O., Y.Ö., Literature Search: M.Ç., T.B., Writing: M.Ç., T.B.

Conflict of Interest: The authors declare no conflict of interest.

Financial Disclosure: The authors declare that this study has not received any financial support.

\section{References}

1. WHO. Hepatitis C Fact Sheet. Available from: https://www.who. int/news-room/fact-sheets/detail/hepatitis-c. (Last accessed on 2017 Oct 27).

2. Smith DB, Bukh J, Kuiken C, Muerhoff AS, Rice CM, Stapleton JT, Simmonds P. Expanded classification of hepatitis $C$ virus into 7 genotypes and 67 subtypes: updated criteria and genotype assignment web resource. Hepatology. 2014;59:318-27.

3. Okamoto $H$, Kobata S, Tokita H, Inoue T, Woodfield GD, Holland PV, Al-Knawy BA, Uzunalimoglu O, Miyakawa Y, Mayumi M. A second-generation method ofgenotyping hepatitis $C$ virus by the polymerase chain reaction with sense andanti-sense primers deduced from the core gene. J Virol Methods 1996;57:31-45.

4. Davis GL. Hepatitis C virus genotypes and quasispecies. Am J Med. 1999;107:21-26.

5. Naoumov NV. Hepatitis C virus infection in Eastern Europe. J Hepatol. 1999;31:84-87.

6. Trepo $C$, Pradat P. Hepatitis $C$ virus infection in Western Europe. $J$ Hepatol. 1999;31:80-83.

7. Zeytinli UO, Yucel FM, Daldaban Dincer S, Yanılmaz O, Aksaray S, Ozdil K. Distribution of hepatitis $\mathrm{c}$ virus genotypes in the region of Istanbul Northern Anatolian Association of Public Hospitals. Viral Hepat J. 2017;23:10-13.

8. Karabulut N, Alacam S, Yolcu A, Onel M, Agacfidan A. Distribution of Hepatitis C Virüs Genotypes in Istanbul, Turkey. Indian J Med Microbiol 2018; 36:192-196. 
9. Bokharaei Salim F, Keyvani H, Amiri A, Jahanbakhsh Sedifi F, Shakeri R, Zamani F. Distribution of different hepatitis C virus genotypes in patients with hepatitis $C$ virus infection. World $J$ Gastroenterol. 2010;16:2005-2009.

10. Petruzziello A, Marigliano S, Loquercio G, Cacciapuoti C. Hepatitis $\mathrm{C}$ virus (HCV) genotypes distribution: an epidemiological up-date in Europe. Infect Agent Cancer. 2016;11:53.

11. Ozacar T, Altuglu I, Zeytinoglu A et al. Kronik C hepatitinde HCV genotiplerinin dagılımı, Mikrobiyol Bult. 2001;35:451-458.

12. Bozdayi AM, Aslan N, Bozdayi G, Türkyilmaz AR, Sengezer T, Wend U, Erkan O, Aydemir F, Zakirhodjaev S, Orucov S, Bozkaya H, Gerlich W, Karayalçin S, Yurdaydin C, Uzunalimoğlu O. Molecular epidemiology of hepatitis $B, C$ and $D$ viruses in Turkish patients. Arch Virol. 2004;149:2115-2129.

13. Altuglu I, Soyler I, Ozacar T, Erensoy S. Distribution of hepatitis C virus genotypes in patients with chronic hepatitis $C$ infection in western Turkey. Int J Infect Dis. 2008;12:239-244.

14. Celik C, Bakıcı MZ, Kaygusuz R, Erturk R. Sivas yöresindeki HCV genotip dağılımlarının araştırılması. Viral Hepatit Derg. 2010;16:106-110.

15. Kucukoztas MF, Ozgunes N, Yazıcı S. Kronik hepatit C'li hastalarda hepatit $C$ virüsü $(\mathrm{HCV})$ genotipleri ile alanin aminotransferaz ve HCV-RNA düzeyleri arasındaki ilişkinin araştııılması Mikrobiyol Bul. 2010:44:111-115.

16. Gökahmetoğlu $S$, Atalay $M A$, Kılınç $A$. Hepatit $C$ virüs genotiplerinin pirosekanslama yöntemi ile belirlenmesi, Erciyes Tıp Derg. 2011;33:99-102.

17. Kayman T, Karakukcu Ç, Karaman A, Gozutok F. Kayseri bölgesinde Hepatit $C$ virüs enfeksiyonunun genotip dağılımı. Türk Mikrobiyol Cem Derg. 2012;42:21-26.

18. Oztürk $A B$, Doğan UB, Akçaer Oztürk N, Ozyazici G, Demir M, Akin MS, Böngöl AS. Hepatitis C virus genotypes in Adana and Antakya regions of Turkey. Turk J Med Sci. 2014;44:661-665.

19. Kirisci O, Calıskan A, Alkıs Kocturk S, Erdogmus P, Gül M. Kahramanmaraş ili Hepatit $C$ virüs ile enfekte bireylerde genotip dağılımı ve genotipin HCV-RNA yükü ve ALT-AST ilişkisi. Viral Hepatit Derg. 2013;19:67-70.

20. Altuğlu I, Sertöz R, Aksoy A, Gürsel D, Tüzüner U, Günşar F. Possible transmission risks and genotype distribution of hepatitis C virus infection in Western Turkey. Turk J Gastroenterol. 2013;24:349-355.
21. Tezcan S, Ulger M, Aslan G, Yaraș S, Altıntaş E, Sezgin O, Emekdas G, Gürer Giray B, Sungur MA. Determination of hepatitis $C$ virus genotype distribution in Mersin province,Turkey. Mikrobiyol Bul 2013;47:332-338.

22. Buruk CK, Bayramoğlu G, Reis A, Kaklıkkaya N, Tosun I, Aydın F. Determination of hepatitis $C$ virus genotypes among hepatitis $\mathrm{C}$ patients in Eastern Black Sea region, Turkey. Mikrobiyol Bul. 2013;47:650-657.

23. Aktaş O, Özbek A, Aydın H, Özkülekçi MB. Distribution of HCV genotypes in patients of with chronic hepatitis $C$ in the eastern anatolia region. Viral Hepatitis Journal. 2014;20:91-94.

24. Sağlik I, Mutlu A, Öngüt G, Inan D, Öğünç D, Sarinoğlu RC, Özhak Baysan B, Gültekin M, Dilek Çolak D. Distribution of hepatitis $C$ virus genotypes among patients with chronic hepatitis C infection in Akdeniz University Hospital, Antalya, Turkey: five year evaluation. Mikrobiyol Bul. 2014;48:429-437.

25. Borcak D, Çağır Ü, Yalçıner A. Distribution of hepatitis $C$ virus genotypes and their association with serum alanine aminotransferases and quantitative serum HCV RNA levels. ANKEM Derg. 2015;29:36-40

26. Özer Balin Ş, Sağmak Tartar A, Akbulut A, Aşçı Toraman Z. Elazığ ilinde hepatit $C$ virüs genotip dağılımı ve genotipin HCV RNA ve serum alanin aminotransferaz düzeyleri ile ilişkisi. ANKEM Derg. 2017;:31:48-52.

27. Akgün S, Tarhan G, Sayıner HS, Akgün I, Kök S. Adıyaman ilinde hepatit $C$ virüsü genotip dağılımının belirlenmesi. Ortadoğu Tıp Dergisi. 2017;9:1-5

28. Çizmeci Z. Kronik hepatit $\mathrm{C}$ enfeksiyonlu hastalarda hepatit $\mathrm{C}$ virüs genotiplerinin dağılımı. Türk Mikrobiyol Cem Derg. 2016;46:27-32.

29. Aguilera A, Navarro D, Rodríguez-Frias F, Viciana I, MartínezSapiña AM, Rodríguez MJ, Martró E, Lozano MC, Coletta E, Cardeñoso L, Suárez A, Trigo M, Rodríguez-Granjer J, Montiel N, de la Iglesia A, Alados JC, Vegas C, Bernal S, Fernández-Cuenca F, Pena MJ, Reina G, García-Bujalance S, Echevarria MJ, Benítez L, Pérez-Castro S, Ocete D, García-Arata I, Guerrero C, RodríguezIglesias M, Casas P, García F. Prevalence and distribution of hepatitis C virus genotypes in Spain during the 2000-2015 period (the GEHEP 005 study). J Viral Hepat. 2017;24:725-732.

30. Kartashev V, Döring M, Nieto L, Coletta E, Kaiser R, Sierra S, HCV EuResist Study group. New findings in HCV genotype distribution in selected West European, Russian and Israeli regions. J Clin Virol. 2016;81:82-89. 